\title{
Vital Signs Elapsed Time
}

National Cancer Institute

\section{Source}

National Cancer Institute. Vital Signs Elapsed Time. NCI Thesaurus. Code C83456.

The interval between two vital signs reference time points. 